\title{
Sekonder Akciğer Neoplazmlarında Metastazektominin Sağkalım Üzerine Olan Etkisi
}

\author{
The Effect of Metastasectomy on Survival in Secondary Pulmonary Neoplasms
}

\author{
Fatoş KOZANLI ${ }^{1}$, Bekir Sami KARAPOLAT ${ }^{2}$, Atila TÜRKYILMAZ², Celal TEKINBAŞ ${ }^{2}$
}

\begin{abstract}
${ }^{1}$ Kahramanmaraş Sütçü Imam Üniversitesi Tip Fakültesi Göğüs Cerrahi Anabilim Dalı
${ }^{2}$ Karadeniz Teknik Üniversitesi Tip Fakültesi Göğ̈̈s Cerrahisi Anabilim Dalı
\end{abstract}

Geliş Tarihi:03.01.2020 Kabul tarihi:29.01.2020 DOI: 10.17517/ksutfd.669744

\begin{abstract}
Özet
Amaç: Kliniğimizde opere edilen sekonder akciğer neoplazmları incelenerek, primer tümör kontrol altında iken yapılan metastazektominin sağkalım üzerine olan etkilerinin araştırılması.

Gereç ve Yöntemler: Bu çalışmada Ocak 2010 ile Ocak 2015 yılları arasında kliniğimizde sekonder pulmoner neoplazm nedeni ile opere edilen 29 olgu retrospektif olarak incelendi. Olgular yaş, cinsiyet, kardiyopulmoner değerlendirmeler, primer tümörün histopatolojik tipi, sekonder tümörün evresi ve preoperatif radyolojik bulguları, hastalıksız yaşam süreleri, cerrahi insizyon şekilleri ve rezeksiyonun türü, komplet-inkomplet rezeksiyon sayıları, nodül sayıları, sağkalım süreleri açısından değerlendirildi.

Bulgular: Olguların 9’u kadın (\%31), 20'si (\%69) erkek idi. En küçük yaş 18, en büyük yaş 75 (ortalama 56士12) idi. Olgularımıza toplam 38 cerrahi girişim uyguland. En sık uygulanan cerrahi girişim 24 olguda (\%63.2) posterolateral torakotomi (PLT), 14 olguda (\%36.8) video yardımlı torakoskopik cerrahi (VATS) idi. Bir yıllık sağkalım \%96, 3 yıllık sağkalım \%72 ve 5 yıllık sağkalım \% 58 olarak bulundu. Primer tümörün histopatolojik tipine göre en sık karsinom (\%79.3), ikinci sıklıkta sarkom (\%17.2) tespit edildi. Sarkomlarda pulmoner metastazektominin 5 yıllık sağkalım \%40, karsinomlarda \%73.5 olarak hesaplandı.

Sonuç: Primer malignitesi kontrol altında ve ekstrapulmoner metastazı olmayan sekonder pulmoner neoplazmlı olgularda, metastazektomi, özellikle karsinomlarda sağkalıma önemli ölçüde katkı sağlanmaktadır. Çalışmamızda sekonder tümörün evresinin ve primer tümörün histopatolojik tipinin sağkalımı belirleyen esas faktörler olduğu görüldü.
\end{abstract}

Anahtar kelimeler: Sekonder pulmoner neoplazm, metastazektomi, sağkalım

\section{Abstract}

Objective: To investigate the effects of metastasectomy on survival by examining secondary lung neoplasms operated in our clinic while primary tumor is under control.

Material and Methods: In this study, 29 cases operated in our clinic for secondary pulmonary neoplasm were evaluated retrospectively between January 2010 and January 2015. Patients were evaluated in terms of age, sex, cardiopulmonary evaluations, histopathological type of primary tumor, stage and preoperative radiological findings of the secondary tumor, disease-free survival, surgical incision types and type of resection, complete-incomplete resection numbers, nodule counts and survival time.

Results: Nine of the cases were female (31\%) and 20 (69\%) were male. The youngest age was 18, the highest age was 75 years (mean $56 \pm 12$ years). A total of 38 surgical procedures were performed. The most common surgical intervention was posterolateral thoracotomy (PLT) in 24 cases (63.2\%) and video assisted thoracoscopic surgery (VATS) in 14 cases (36.8\%). According to histopathological type of primary tumor, carcinoma was the most common (79.3\%) and sarcoma was the second common (\%17.2). The 5-year survival rate of pulmonary metastasectomy in sarcomas was $40 \%$ and $73.5 \%$ in carcinomas.

Conclusion: Survival of metastasectomy, especially in carcinomas, is a significant contributor in cases with secondary pulmonary neoplasm with primary malignancy under control and without extrapulmonary metastasis. In our study, it was seen that the stage of secondary tumor and histopathological type of primary tumor were the main factors determining survival.

Keywords: Secondary pulmonary neoplasm, metastasectomy, survival

Yazışma Adresi: Fatoş Kozanlı Kahramanmaraş Sütçü İmam Üniversitesi Tıp Fakültesi Göğüs Cerrahi Anabilim Dalı, Kahramanmaraş Tel: 05052231984 Mail: opdrfatoskozanli@gmail.com

ORCID NO (Sirasıla): 0000-0001-7664-2657, 0000-0001-9361-9483, 0000-0002-4827-7469, 0000-0001-8309-5348 


\section{GİRIŞ}

Malign tümörler kanlanma özelliğinden dolayı metastazlarını öncelikle ve sıklıkla akciğerlere yapmaktadırlar. Akciğer metastazların sık görüldügü bir organdır. Sekonder pulmoner neoplazmlar çoğunlukla asemptomatiktir ve sıklıkla rutin radyolojik takiplerde saptanır. Akciğer metastazlarının tespitinde en değerli radyolojik tetkikler PAAG ve toraks BT'dir. Pulmoner metastazektomide amaç mümkün olduğunca sağlam parankim parankim dokusunun korunarak cerrahi sınırları tümör negatif olan güvenli rezeksiyon yapmaktır. Sekonder pulmoner neoplazmlar, primer malign tümörlerin sistemik metastazlarının bir parçası olmakla birlikte sahip oldukları özellikler bakımından ayrı olarak incelenmesi gereken bir konudur. Primer tümörün lokal olarak kontrolü; cerrahi, kemoterapi (KT) ve radyoterapi ile sağlanabilse de sistemik metastazlar için tedavi şekli hala tartışmalıdır (1-3). Sekonder pulmoner neoplazmlar için cerrahi rezeksiyon, belli strateji ve kriterler uygulandığında etkin bir tedavi yöntemidir. Bunlar; primer tümörün kontrol altında olması, ekstratorasik metastaz olmaması, lezyonların komplet rezeksiyona uygun olması ve cerrahi sonrası kardiyopulmoner rezervin uygun olmasıdır (4-6). Hastalığın prognozunda, yaş, cinsiyet, cerrahi girişim ve rezeksiyon şekli etkili olmayıp, tümör histolojisi, hastalıksız yaşam süresi, metastaz sayısı, mediastinal lenf nodu tutulumu ve ek tedavi alımı önemli prognostik göstergelerdir. Genel olarak pulmoner metastazların cerrahi rezeksiyonu güvenli ve efektif bir tedavi şeklidir (7).

$\mathrm{Bu}$ çalışmanın amacı primer tümör kontrol atındayken yapılan pulmoner metastazektominin sağkalım üzerine etkisinin araştırılmasıdır.

\section{GEREC ve YÖNTEMLER}

\section{Çalışma protokolü}

Çalışmamızda Ocak 2010 ile Ocak 2015 yılları arasında kliniğimizde sekonder pulmoner neoplazm nedeni ile opere edilmiş 29 olgu retrospektif olarak incelenmiştir. Analiz kriterlerimiz; olguların yaşı, cinsiyeti, kardiopulmoner değerlendirmeler, primer tümörün histopatolojik tipi, sekonder tümörün evresi ve preoperatif radyolojik bulguları, hastalıksız yaşam süreleri, cerrahi insizyon şekilleri, rezeksiyonun türü, komplet-inkomplet rezeksiyon sayıları, nodül sayıları ve sağkalım süreleri idi.

Olgulara ait bilgilere, elektronik ortamda hastanemize ait merkezi sistem bilgi işlem sisteminden, arşivdeki hasta dosyalarından, poliklinik kayıtlarından, ameliyat notlarından, hastane dışında yaşamını yitirenlerin ölüm tarihleri elektronik bilgi sisteminden tespit edilerek ve gerekli durumlarda hastalarla telefonla bağlantı kurularak ulaşıldı.

Metastazektomi yapılan hastaların tümünün primer neoplazmları daha önce cerrahi olarak çıkarılmış ve kontrol altındaydı. Hastalar preoperatif olarak fizik muayene, akciğer grafileri, rutin biyokimya tetkikleri ve elektrokardiografi ile değerlendirildi. Tüm hastalara solunum fonksiyon testleri yapılarak olası anatomik rezeksiyonlar için gerekli solunum rezervine sahip olup olmadıkları tespit edildi. Medikal olarak cerrahiye uygun olan hastalar opere edildi. Bu olguların Bilgisayarlı Toraks Tomografileri (BT) preoperatif olarak incelenerek metastazların sayı ve lokalizasyonları belirlendi.

Olgularımıza, klinik uygunluklarına göre tarama amaçlı tüm vücut onkolojik pozitron emisyon tomografisi (PET)/ BT veya BT, beyin metastazları olup olmadığının tespit edilmesi açısından ise Beyin Manyetik Rezonans Görüntüleme (MR) çekildi. Cerrahi teknik ve insizyon şekline; nodüllerin lokalizasyonu, büyüklüğü ve sayılarına göre karar verildi.

Çalışmamız Helsinki Deklerasyonu'na uygun olarak yürütüldü ve çalışmamız için Karadeniz Teknik Üniversitesi Tıp Fakültesi Klinik Araştırmalar Etik Kurulu'ndan onam alındı (Etik kurul karar no: 2015/74).

\section{Sağkalım analizleri ve istatistikler}

Verilerin istatistiksel analizinde, örneksel verilerde ortalama ve standart sapma niteliksel verilerde ise sayı ve yüzde kullanıldı. Olguların dosya bilgilerinden elde edilen tarihler aracılığıyla Kaplan Maier sağkalım analizleri testi yapıldı. Değişik faktörlere göre sağ kalımları karşılaştırmak için logrank testi kullanıldı. İstatistiksel anlamlılık için $p$ değerinin 0.05’ten küçük olmasına dikkat edildi.

\section{BULGULAR}

Bu çalışmadaki 29 olgunun 20’si erkek (\%69), 9‘u kadındı (\%31). En küçük yaş 18, en büyük yaş 75 idi. Yaş ortalaması $56 \pm 12$ olarak hesapland. Histopatolojik dağılım olarak 23 karsinom (\%79.4), 5 sarkom (\%17.2) ve 1 (\%3.4) germ hücreli tümör tanısı almış hasta tespit edildi. Hastalıksız yaşam süresi, karsinomlarda ortalama 28 ay, sarkomlarda ortalama 39.6 ay ve germ hücreli tümörü olan tek hastada 3 ay idi. Hastaların tamamına yakını asemptomatik olup sadece 2 (\% 6.9) hastada preoperatif nefes darlığı, 1 hastada (\%3.4) öksürük mevcuttu. Metastazektomi için gerekli kriterleri sağlayan hastalara sağ ve sol PLT, sağ ve sol VATS uyguland..

Yirmidokuz hastaya 38 cerrahi girişim uygulandı. PLT insizyonu ile 8 (\%21) olguda lobektomi, 1 olguda (\%3.4) nüksün gögüs duvarı invazyonu ile birlikte olması nedeni ile remetastazektomisi göğüs duvarı rezeksiyonu ile birlikte 'en blok' rezeksiyon şeklinde yapıldı. 13 (\%34.2) olguda VATS ile wedge rezeksiyon, 13 (34.2) olguda torakotomi ile wedge rezeksiyon uyguland. Torakotomi 4 hastada 1'er kez tekrarland. Sarkom metastazı olan 1 olguda (\% 3.4) nüks nedeni ile toplam 4 kez metastazektomi yapıldı. Bunun dışında 3 olguda (\%10.3) daha nüks nedeni ile remetastazektomi yapılarak toplam 4 olguda (\%13.7) remetastazektomi yapıldı. Sağ PLT kesisi 11 (\%28.4) olguda ilk metastazektomi, 2 (\%5.3) olguda remetastazektomi olmak üzere toplam 13 (\%34.2) kez; sol PLT 9 (\%23.6) olguda ilk metastazektomi, 2 (\%5.3) olguda remetastzektomi olmak üzere toplam 11 (28.9) kez; sağ VATS 9 (\%23.6); sol VATS 5 (\%13.2) kez uyguland. Tümörün sant- 
ral yerleşimli olarak tespit edildiği 6 hastada endobronşiyal tutulum değerlendirilmesi açısından rijit bronkoskopi yapıldı. Bu hastaların hiçbirinde endobronşiyal tutulum tespit edilmedi.

Ortalama postoperatif yatı̧s süresi 5.5 gün idi. Bir hastada (\%3.4) postoperatif kanama gelişti ve revizyon yapıldı. Üç (\%10.3) olguda müdahalesiz düzelen hava kaçağı gelişti. Bir hastada ileus (\%3.4) ve 1 hastada atrial fibrilasyon (\%3.4) görüldü. Bu olguların 2 'si de medikal tedavi ile erken dönemde düzeldiler.

Metastazektomi kriterlerini sağlayan olgular; yaş, cinsiyet, primer tümörün histopatolojik tipi, lokalizasyon ve tedavilerine göre değerlendirildi (Tablo1).

Postoperatif patolojik inceleme ile tüm olguların metastezektomi materyallerinde cerrahi sinırları tümör negatif idi. Ameliyat sırasında makroskopik tutulumu olduğu düşünülen 8 (27.5) olguya mediastinal lenf nodu diseksiyonu yapildı. Bunlardan 1 olgunun (\%3.4) patoloji sonucunda 3 adet hiler lenf nodunda (N1) metastaz saptandi. Olgulardan 7'sine (\%24) ameliyat öncesi neoadjuvan KT ve 21 olguya ise (\%72.4) adjuvan KT verildi.

Olgularımız Uluslararası Akciğer Metastazı Kayıtları Merkezi (UAMK) evreleme sistemine göre değerlendirildiğinde; evre I 'de 3 olgu (\%10.3), evre II'de 12 olgu (\%41.4), evre III'de 14 olgumuz (\%48.3) mevcuttu.

Preopertif olarak tüm hastalarda radyolojik olarak metastazla uyumlu 62 nodül (ortalama nodül sayısı 2.1) tesbit edilmiştir. Ameliyat sonrasında tespit edilen nodül sayısı 68 (ortalama nodül sayısı 2.3) olarak bulunmuştur. Burada cerrahi sirasinda 24 (\%82.7) olguda radyolojik olarak tespit edilen ile aynı sayıda, 4 (\%13.8) olguda daha fazla ve 1 olguda (\%3.4) daha az sayıda nodül tespit edildi.

Metastatik nodüllerin dağılımı 22 olguda (\%75.8) tek taraflı ve 7 olguda (\%24.2) iki taraflıdd. Primeri karsinom olan 15 olguda (\%51.7) ve sarkom olan 2 olguda (\%6.9) ise multipl metastaz mevcuttu.

Kisaltmalar: KT: Kemoterapi; RT: Radyoterapi.

\section{Sağkalım}

Olgular yaş, cins, primer tümörlerinin ilk tanı aldıkları tarih, hastalıksız yaşam süreleri, evreleri, son kontrol ve ölenler için ölüm tarihlerini de içeren detaylı sağkalım analizleri ile değerlendirilmiş olup sonuçlar Tablo 2'de gösterilmiştir.

Metastazektomi yapilan hastalar 7.8-181 ay arasında takip edildi (Tablo 2). Ortalama takip süresi $45 \pm 16.3$ ay olarak hesapland. Ondokuz olgu (\% 65.5) halen takiptedir ancak 10 hasta (\%34.5) kaybedilmiştir (Grafik 1).

Pulmoner metastazektomi yapılan tüm olgularda 1 yıllık sağkalım \%96.3 yıllık sağkalım \%72 ve 5 yıllık sağkalım $\% 58$ olarak hesaplandı. Burada sağkalıma katkı ortalama 7 ay olarak tespit edildi.

Evrelere göre sağkalım incelendiğinde evre I'de tüm hastalar halen takipte olup 5 yıllık sağkalım oranı $\% 100$ olarak hesaplandı. Evre II’de 1 yıllık sağkalım oranı \%91.7, 3 yıllık sağkalım oranı $\% 82.5$ ve 5 yıllık sağkalım oranı $\% 82.5$; evre III’te 1 yıllık sağkalım oranı \%92; 3 yıllık sağkalım oranı \%61.5 sağkalım oranı \%34.2 olarak hesaplandı. Evre II'de 12 olgudan 3 tanesi ve evre III'te 7 tanesi ilerleyen takiplerinde kaybedildiler (Grafik 2).

Cinsiyete göre sağkalım oranları erkek cinsiyet için 1 yıllık sağkalım \%97, 3 yıllık sağkalım \%63.8 ve 5 yıllık sağkalım \%46.5, kadın cinsiyet için 1 yıllık sağkalım \%100, 3 yıllık sağkalım \%87.5 ve 5 yıllık sağkalım \%45 olarak hesaplandı. Cinsiyetler arasında sağkalım açısından istatisitksel olarak anlamlı fark tesbit edilmedi ( $\mathrm{p}>0.227$ ). Primer tümörün histopatolojik dağılımına göre sağkalıma katkı karsinomlarda ortalama 5 ay, sarkomlarda ortalama 16.4 ay olarak hesaplanmıştır. Tek vaka olan germ hücreli tümörde ise sağkalıma katkı sağlanamamıştır.

Çalışmamızda 6 hastanın primer malignitesi kolon adenokarsinom (\%20.7), 5 hastanın sarkom (\%17.3), 4 hastanın mesane adenokarsinom (\%13.6), 3 hastanın larinks skuamoz hücreli karsinom (\%10.4), 3 hastanın prostat adenokarsinom (\%10.4), 2 hastanın meme adenokarsinomu (\%6.9), 2 hasta cilt squamoz hücreli karsinom (\%6.9) 1 hastanın renal hücreli karsinom (\%3.4), 1 hastanın over adenokarsinomu (\%3.4), 1 hastanın endometrium adenokarsinomu (\%3.4) 1 hastanın germ hücreli tümör (\%3.4) olarak tespit edilmiştir. Ürolojik karsinomlar topluca ele alındığında \%27.6'lık oranla en yüksek paya sahip oldukları görülmektedir.

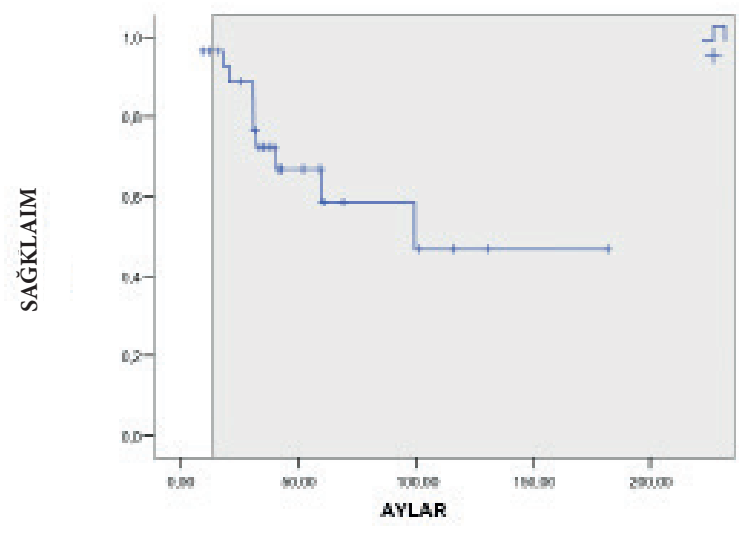

Grafik 1. Sağkalım eğrisi

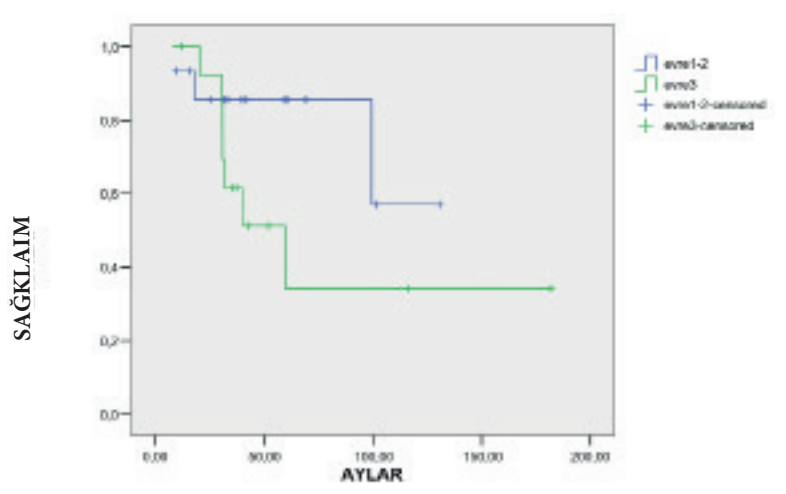

Grafik 2. Evrelere göre sağkalım eğrisi 


\section{Tablo 1. Primer Tümörün özellikleri}

\begin{tabular}{|c|c|c|c|c|c|}
\hline Hasta & Yaş & Cinsiyet & $\begin{array}{l}\text { Primer tümör histopatolojik } \\
\text { tip }\end{array}$ & Lokalizasyon & Tedavi \\
\hline 1 & 65 & K & Adenokarsinom & Sağ meme & Cerrahi+ KT+ RT \\
\hline 2 & 50 & $\mathrm{E}$ & Leimyosarkom & Sağ uyluk & Cerrahi \\
\hline 3 & 18 & $\mathrm{E}$ & $\begin{array}{l}\text { Nonseminomatöz germ } \\
\text { hücreli tümör (testis) }\end{array}$ & Testis & Cerrahi \\
\hline 4 & 75 & $\mathrm{E}$ & Squamöz hücreli karsinom & Larinx & Cerrahi+ KT+ RT \\
\hline 5 & 63 & $\mathrm{E}$ & Squamöz hücreli karsinom & Cilt & Cerrahi \\
\hline 6 & 64 & $\mathrm{E}$ & Squamöz hücreli karsinom & Larinks & Cerrahi+KT+RT \\
\hline 7 & 50 & $\mathrm{~K}$ & Malign mezenkimal tümör & Sağ gluteal bölge & Cerrahi \\
\hline 8 & 57 & $\mathrm{E}$ & Adenokarsinom & Kolon & Cerrahi \\
\hline 9 & 61 & $\mathrm{~K}$ & Adenokarsinom & Kolon & Cerrahi+KT \\
\hline 10 & 55 & $\mathrm{~K}$ & Adenokarsinom & Endometrium & Cerrahi \\
\hline 11 & 66 & $\mathrm{E}$ & Adenokarsinom & Prostat & Cerrahi \\
\hline 12 & 37 & $\mathrm{~K}$ & Adenokarsinom & Over & Cerrahi+KT \\
\hline 13 & 48 & $\mathrm{E}$ & Bazal hücre karsinom & Perianal bölge & Cerrahi \\
\hline 14 & 55 & $\mathrm{E}$ & Adenokarsinom & Kolon & Cerrahi \\
\hline 15 & 57 & $\mathrm{~K}$ & Adenokarsinom & Sol meme & Cerrahi+KT \\
\hline 16 & 44 & $\mathrm{E}$ & Fusiform hücreli sarkom & Sol uyluk & Cerrahi \\
\hline 17 & 50 & $\mathrm{E}$ & Adenokarsinom & Prostat & Cerrahi \\
\hline 18 & 38 & $\mathrm{~K}$ & Kondroblastik osteosarkom & Sol omuz & Cerrahi \\
\hline 19 & 61 & $\mathrm{E}$ & Squamoz hücreli karsinom & Larinks & Cerrahi+KT+RT \\
\hline 20 & 73 & $\mathrm{E}$ & Adenokarsinom & Prostat & Cerrahi \\
\hline 21 & 70 & $\mathrm{E}$ & Adenokarsinom & Mesane & Cerrahi \\
\hline 22 & 68 & $\mathrm{~K}$ & Adenokarsinom & Kolon & Cerrahi \\
\hline 23 & 72 & $\mathrm{E}$ & Adenokarsinom & Kolon & Cerrahi \\
\hline 24 & 61 & E & Papiller ürotelial karsinom & Mesane & Cerrahi \\
\hline 25 & 55 & $\mathrm{E}$ & Adenokarsinom & Kolon & Cerrahi \\
\hline 26 & 56 & $\mathrm{~K}$ & Malign fibröz histiyositom & Sol ayak bileği & Cerrahi \\
\hline 27 & 56 & $\mathrm{E}$ & Şeffaf hücreli renal karsinom & Sol böbrek & Cerrahi+KT \\
\hline 28 & 51 & $\mathrm{E}$ & Papiller ürotelial karsinom & Mesane & Cerrahi \\
\hline 29 & 57 & $\mathrm{E}$ & Papiller ürotelial karsinom & Mesane & Cerrahi \\
\hline
\end{tabular}




\begin{tabular}{|c|c|c|c|c|c|c|c|}
\hline Hasta no & Yaş & Cins & İlk tanı & $\begin{array}{l}\text { Hastalıksız } \\
\text { yaşam süresi }\end{array}$ & Evre & Son kontrol tarihi & Eks \\
\hline 1 & 65 & K & 27.05 .2011 & $18 \mathrm{Ay}$ & III & 03.09.2015 & $0^{*}$ \\
\hline 2 & 50 & E & 16.08 .2011 & $20 \mathrm{Ay}$ & III & 03.02 .2014 & 24.02.2014 \\
\hline 3 & 18 & E & 16.03 .2011 & 3 Ay & III & 01.12 .2011 & 21.11 .2012 \\
\hline 4 & 75 & E & 07.01.2012 & 20 Ay & III & 02.02 .2015 & $0^{*}$ \\
\hline 5 & 63 & E & 25.11 .2010 & 30 Ay & I & 19.11 .2015 & $0^{*}$ \\
\hline 6 & 64 & E & 08.10 .2012 & $2 \mathrm{Ay}$ & III & 03.09 .2015 & $0^{*}$ \\
\hline 7 & 50 & K & 05.09 .2014 & 11 Ay & III & 02.09 .2015 & $0^{*}$ \\
\hline 8 & 57 & E & 15.09 .2012 & $15 \mathrm{Ay}$ & II & 10.01 .2012 & 24.04 .2012 \\
\hline 9 & 61 & K & 28.01 .2013 & 11 Ay & II & 02.11 .2015 & $0^{*}$ \\
\hline 10 & 55 & K & 07.08.2012 & 20 Ay & II & 10.03.2015 & $0^{*}$ \\
\hline 11 & 66 & E & 11.12 .2007 & 31 Ay & III & 10.05 .2012 & 07.11 .2012 \\
\hline 12 & 37 & K & 10.09 .2010 & 48 Ay & II & 27.07.2015 & $0^{*}$ \\
\hline 13 & 48 & E & 22.03.2007 & $70 \mathrm{Ay}$ & II & 25.07 .2015 & $0^{*}$ \\
\hline 14 & 55 & E & 23.03 .2011 & 12 Ay & III & 01.10 .2013 & 07.10 .2013 \\
\hline 15 & 57 & K & 25.06 .2012 & 3 Ay & II & 27.09 .2015 & $0^{*}$ \\
\hline 16 & 44 & K & 10.07 .2007 & 70 Ay & II & 10.01 .2015 & 10.09 .2015 \\
\hline 17 & 50 & E & 28.12.2011 & 3 Ay & III & 09.07.2015 & $0^{*}$ \\
\hline 18 & 38 & K & 24.06 .2010 & $1 \mathrm{Ay}$ & III & 07.08.2010 & 07.02.2013 \\
\hline 19 & 61 & E & 12.12 .2003 & 80 Ay & I & 03.09.2014 & $0^{*}$ \\
\hline 20 & 73 & E & 24.09 .2011 & 4 Ay & II & 20.03 .2013 & 25.03.2013 \\
\hline 21 & 70 & E & 19.03.2010 & $12 \mathrm{Ay}$ & II & 20.11 .2015 & $0^{*}$ \\
\hline 22 & 68 & K & 15.03 .2012 & $18 \mathrm{Ay}$ & II & 28.08 .2015 & 01.03.2017 \\
\hline 23 & 72 & E & 23.08 .2013 & $15 \mathrm{Ay}$ & II & 26.09 .2015 & $0^{*}$ \\
\hline 24 & 61 & E & 14.04 .2008 & 78 Ay & III & 29.07 .2011 & 03.08.2011 \\
\hline 25 & 55 & E & 20.03 .2011 & 12 Ay & III & 01.08 .2013 & 01.10 .2013 \\
\hline 26 & 56 & K & 15.12 .2000 & 96 Ay & III & 19.11.2015 & $0^{*}$ \\
\hline 27 & 56 & E & 04.05 .2006 & 108 Ay & III & 18.11 .2015 & $0^{*}$ \\
\hline 28 & 51 & E & 07.07.2014 & 1 Ay & II & 30.10 .2015 & $0^{*}$ \\
\hline 29 & 57 & E & 09.02.2015 & 9 Ay & I & 21.11 .2015 & $0^{*}$ \\
\hline
\end{tabular}

\section{TARTIȘMA}

Primer malign tümörlerin akciğer metastazları sistemik metastazlar içerisinde özel bir yere sahiptir. Primer malign tümör cerrahi ve radyoterapi ile lokal olarak tedavi edilse de sistemik metastazlar için uygulanacak tedavi uygulamaları tartışılmaya devam etmektedir (3). Bizim çalışmamızda hasta sayısının kısıtlı olması, yaş, cinsiyet, primer tümör histolojisi, metastatik hastalığın genişliği, cerrahi teknikler ve ek tedavi yaklaşımları açısından heterojenlik tespit edilmiş ve geniş serilerde dahi uygun bir sınıflandırma yapmanın güç olacağı kanaati oluşmuştur.

Çalışmamızda primer malignitesi kontrol altında olan tüm olgulara posteroantero akciğer grafisi, tüm batın BT, gerekli görülen olgularda batın ultrason (US), kranial MR veya kranial BT, gereklilik görülen hastalara da PET/BT ile tarama yaptık. Bu tetkiklerden özellikle PET/BT genel bir metastaz değerlendirmesi yapması açısından özellikle faydalıdır. Ancak 1 cm'den küçük metastazların 5- FDG (5-Florodeoksiglukoz ) tutmayacağı bilinmeli ve cerrahi esnasında ekstra nodüller aranmalıdır.

Sekonder pulmoner neoplazmlarda, özellikle toraks BT'de tespit edilen nodül sayısının cerrahi esnasında tespit edilen nodül sayısından \%50 düşük olduğu bildirilmiștir $(8,9)$. Çalışmamızda da preoperatif toraks BT'de tesbit edilen toplam nodül sayısı 62 iken postoperatif tümör pozitif nodül sayıs 68 olup Toraks BT'nin tümör pozitif nodül tespit etmedeki doğruluk oranı $\% 91$ olarak bulunmuştur. Nedeninin 
yeni geliştirilen ince kesit ve aksiyel, koronal ve sagittal düzlemde üç boyutlu görüntüleme imkanına sahip teknolojik cihazların kullanılmaya başlanması olduğu düşünülmüştür. Geri kalan \%9'luk grup düşünülerek cerrahi sırasında dikkatli palpasyon yapılması, tesbit edilen tümörlerin tamamının çıkarılmasına imkan verecektir. Ayrıca bu yaklaşım şekli gereksiz remetastazektomiyi de önleyecektir.

Metastazektomide PLT ve VT en sik kullanılan cerrahi yaklaşım metodlarıdır (10). Yapılan bir çalışmada torakotomi veya median sternotomi uygulanarak tespit edilen nodüllerin VATS ile belirlenemediği görülmüştür (11). Klinik çalışmamızda literatürle benzer şekilde, 29 olguya yapılan 38 cerrahide \%63.1 oranında PLT, \%36.9 oranında VATS tercih edilmiştir. Median sternotomi bu serideki olgularda tercih edilmemiştir. Özellikle posterior ve sol alt lob lokalizasyonlu lezyonlara ulaşım güçlüğü nedeni ile median sternotomi yerine tüm nodülleri palpe etme olanağımızın daha yüksek olacağı ardışık bilateral PLT insizyonu kullanılmıştır.

Cerrahi yapılırken mümkün olduğunca sağlam parankimi korumak esas alınırken cerrahi sınırların güvenli ve tümör negatif olmasından emin olmak gereklidir. Parankimin korunduğu ancak cerrahi sinırların tümör negatif olmadığı olgularda metastazektominin sağkalıma katkısı olmayacaktır $(12,13)$. Bu nedenle santral yerleşimli lezyonlarda cerrahi sınırın tümör negatif olmasının diğer rezeksiyon türleri ile mümkün olamayacağı düşünülen olgularda lobektomi yapılmiştır.

Lobektomi bir olguda sağ alt lobda multipl (5 adet) metastaz nedeni ile, 2 olguda transtorasik ince iğne aspirasyon biyopsi sonuncunun adenokarsinom gelmesi ve primer-metastaz ayrımı yapılamaması nedeni ile ve 1 olgularda da tümörün santral olması nedeni ile yapılmıştır ve bu oranlar literatürle uyumludur (14-16).

Bu çalışmada 5 yıllık sağkalım oranları evre I'de \% 100, evre II'de 91.7 ve evre III'de \%50 olarak hesaplanmış olup literatürde verilen oranlardan daha iyidir (17-19). Bu özellikle yeni teknolojiye sahip görüntüleme yöntemleri ile tespit edilen nodüllerin doğruluk oranın yüksek olması ve bizim peroperatif tespit ettiğimiz ilave nodüllerin eksizyonu ile ilişkilidir. Bu evreleme sistemi yaygın olarak kullanım görmemekle beraber yeni klinik çalışmalar doğrultusunda geliştirilebilecek henüz alternatifi olmayan bir sistem olarak düşünülmektedir. Sarkom ve melanomlarda fazla olmak üzere metastazektomi sonrası nüksler görülebilmektedir. $\mathrm{Bu}$ olgularda metastazektomi kriterleri sağlanabiliyorsa remetastazektomiler yapılabilir $(1,4)$. Çalışmamızda 4 (\%10.6) olguda remetastazektomi yapılmış ve sağkalıma ortalama 4.5 ay katkı sağlanmıştır. Genel olarak çalışmamızda sağkalıma katkı süreleri karsinomlu olgularda 5 ay, sarkomlarda 16.4 ay olarak hesaplanmıştır.

Olguların tek tek primer organ ve histopatolojik tiplere göre sağkalıma katkıları hesaplandığında; toplam 2 (\%6.9) olgu olan meme adenokarsinomlarında 5 yıllık sağkalımın $\% 100$ olduğu ve bu gruptaki tüm hastaların takip edildikleri görülmektedir. Burada sağkalıma katkı ortalama 14.5 ay ve ortalama takip süreleri 44 ay olarak hesaplanmıştır.

Meme adenokarsinomlu olgularımızdaki sağkalım oranlarımız literatürdekinden daha fazladır $(11,12)$. Çalışmamızda meme karsinomlu olguların takibinde rutin PAAG'lerinin yanı sıra yapılan diğer görüntüleme yöntemleri toraks duvarında yer alan bir organ olması nedeni ile pulmoner parankimi de görüntülemeye olanak sağladığından meme karsinomu metastazlarının erken evrede tanınma şansını yakaladıklarını düşünmekteyiz.

Mesane, prostat ve renal hücreli karsinom olgularını tek bir grup altında toplamak ve üroloji grubu hastalar olarak tanımlamak gerekirse toplam 8 olgu (\%27.5) ile en fazla olgunun bu grupta olduğu ve en yüksek oranda 5 yillık sağkalıma sahip oldukları görülmektedir (13). Yaptığımız çalışmada Üroloji kliniğimizin, takip ettikleri primer neoplazm olgularında rutin PAAG'lerinde pulmoner nodülleri tespit edebildiklerini ve ayrıca çekilen batın BT'lerin üst kesitlerine giren pulmoner parankimde tesadüfen tespit edilen nodülleri dikkate aldıkları görülmüştür.

Sarkom grubuna giren 5 olguda (\%17.3) 5 ylllık sağka$\lim \% 40$ olup metastazektominin sağkalıma katkısı 16.4 ay olarak hesaplamıştır. Sarkom tanısı olan hastalar ortalama 12 ay takip edilmişlerdir. Casson ve ark.'ları 1992 yılında sarkomlar için pulmoner metastazektomi sonrası 5 yıllık sağkalım oranlarını \%25 olarak bildirmiş olup bizim çalışmamızda daha yüksek oranda sağkalım oranı tesbit edilmiştir (14-16). Çalışmamızda remetastazektomiler en fazla sarkom grubunda yapılmış olup tek seferde en fazla sayıda nodül de bu grupta çıkarılmıştır. Burada rezidü tümör bırakılmamasının ve olguların sıkı takip edilerek yeni tespit edilen nodüllere zamanında yapılan remetastazektominin sağkalımı akciğer metastazektomisi sonrası adjuvan tedavi konusunda randomize bir çalışma yoktur (17). Ancak çalışmamızda cerrahi sonrası özellikle multipl metastazlı hastalarda adjuvan KT uygulanmıştır. Adjuvan KT uygulanan hastaların, uygulanmayanlara oranla sağkalımları arasında anlamlı fark bulunamamıştır. Olgu sayımızın az olması, geniş örnekleme kümemiz olmaması nedeni ile bu konuda çok merkezli daha kapsamlı çalışmalara ihtiyaç olduğu kanaatindeyiz.

Metastatik nodüllerin tamamı radyolojik olarak tesbit edilemediğinden olgularda intraoperatif olarak akciğerin değerlendirilmesi dikkatle yapılmalı ve ek nodül varlığı araştırılmalıdır. Bu konuda sağkalımı belirleyen esas faktörlerin tümör histopatolojisi ve hastalığın yaygınlık derecesi olduğu düşünülmektedir.

Metastazlar kontrolsüz tümör büyümesiyle beraber hastalık progresyonundaki hızlı ilerleyişin habercisi olmaktadır (20). Ancak izole akciğer metastazları olumlu tümör biyolojisi izlemektedir (21). Bu hastalar birden çok organ metastazı bulunan olgulara oranla lokal ve lokal-sistemik tedavi uygulamaları için daha elverişlidir. Dolayısı ile izole akciğer metastazlı olgular tedavi edilemez olarak kabul edilmemelidir. Sekonder pulmoner neoplazmlarda amaç hastalıksız yaşam 
süresini uzatmak, sağkalıma katkı sağlamak ve küratif tedavi elde etmektir.

Sonuç olarak; Pulmoner metastazektomide cerrahi yaklaşım şekilleri, nodüllerin sayı ve lokalizasyonuna göre belirlenmelidir. Bütün nodüllerin çıkarılması esas olduğundan gereğinde iki seanslı girişimler de yapılabilir. Radyolojik olarak varlığı ortaya koyulan nodüller operasyon sırasında da ortaya koyulmalı, bunun dışında radyolojik olarak tesbit edilemeyen nodüllerin var olabileceği de akılda tutularak dikkatli manuel palpasyon yapılmalı ve tespit edilen tüm nodüller çıkarılmalıdır. Metastazektomi sonrası en iyi prognoz tek nodülü olan olgularda sağlanmaktadır. Hastalıksız sürenin uzun olması metastazektomilerde prognozu olumlu etkileyen faktördür. Evre sağkalımı etkileyen en önemli prognostik faktördür. Sekonder pulmoner neoplazmlarda cinsiyet metastazektominin surve katkısını etkilememektedir. Primer tümörün histopatolojik türü de sekonder pulmoner neoplazmlarda pulmoner metastazektomi sonrası sağkalımı etkileyen önemli prognostik faktörlerden biridir.

Malignite ile ilgili tüm uzmanlık dallarında, primeri kontrol alınmış tümör olgularında mutlaka akciğerleri değerlendirmeye yönelik görüntüleme yöntemlerinden faydalanılmalı, izole pulmoner metastaz olasılığ de, gögüs cerrahisinin görüşü alınarak metastazektomi kriterlerini sağlayan olgular cerrahiye verilmelidir.

Çıkar Çatışması ve Finans Durumu: Çalışmamız bir kurum ve kuruluşça finanse edilmemiştir. Bu çalışmada yazarlar arasında herhangi bir konuda çıkar çatışması bulunmamaktadir.

\section{KAYNAKLAR}

1. Pastorino U, Friedel G, Buyse M, Ginsberg RJ, Girard P, Goldstraw P, et al. Long-term results of lung metastasectomy: prognostic analyses based on 5206 cases. The International Registry of Lung Metastases. J Thorac Cardiovasc Surg. 1997;113:37-49.

2. Putnam JB Jr. Secondary Tumors of The Lung. In Shields TW, Locicero J, Ponn RB, editors. General Thoracic Surgery. 6th ed. Philadelphia: Lippincott Williams \& Wilkins 2005;1831-62.

3. Yüksel M, Kalaycı G. Metastatik akciğer tümörleri. İn: Yüksel M, Kalaycı G (eds). Göğüs Cerrahisi. İstanbul: Bilmedya Grup 2001:307-328.

4. Margaritora S, Porziella V, D’Andrilli A, et al. Pulmonary metastases: can accurate radiological evaluation avoid thoracotomic approach? Eur J Cardiothorac Surg 2002;21: 1111-1114.

5. Parsons AM, Detterbeck FC, Parker LA. Accuracy of helical CT in the detection of pulmonary metastases: is intraoperative palpation still necessary? Ann Thorac Surg 2004;78: 1910-1918.

6. Kondo H, Okumura T, Ohde Y, Nakagawa K. Surgical treatment for metastatic malignancies. Pulmonary metastasis: indications and outcomes. Int J Clin Oncol. 2005;10:81-5.

7. Okur E, Cankurtaran M, Baysungur V, Kır A, Halezeroğlu S, Atasalihi A. Metastatik akciğer tümörlerinde cerrahi tedavi Toraks Derg 2002;3:132-7. 55

8. Younes RN, Haddad F, Ferreira F, Gross JL. Surgical removal of pulmonary metastases: a prospective study in 182 patients. Rev Assoc Med Bras 1998;44:218-25.
9. Gross BH, Glazer GM, Bookstein FL. Multiple pulmonary nodules detected by computed tomography: diagnostic implications. J Comput Assist Tomogr 1985;9:880-5.

10. Kandioler D, Kromer E, Tuchler H, et al: Long term results after repeated surgical removal of pulmonary metastases. Ann Thorac Surg 1998;65:909-12

11. Weinlechner JW. Zur kasuistik der tumoren an der brustwand and deren behandlung.(Resektion der rippen, Eroffnung der Brusthohle, partielle Entfernung der Lungen). Wien Med Wochenschr 1882;32:589

12. Godzinski J, Tournade MF, De Kraker J, Ludwig R, Weirich A, Voute PA, et al. The role of preoperative chemotherapy in the treatment of nephroblastoma: the SIOP experience. Societe Internationale d'Oncologie Pediatrique. Semin Urol Oncol 1999;17(1):28-32.

13. Staren ED, Salerno C, Rongione A, Witt TR, Faber P. Pulmonary resection for metastatic breast cancer. Arch Surg 1992;127:12824. 67

14. Marincola FM, Mark James BD. Selection factors resulting in improved survival after surgical resection of tumors metastatic to the lungs. Arch Surg 1990;125:1387-1393

15. Rööser B, Pettersson H, Alvegård T. Growth rate of pulmonary metastases from soft tissue sarcoma. Acta Oncol 1987;26(6):496

16. Alexander J, Haight C. Pulmonary resection for solitary metastatic sarcoma and carcinoma. Surg Gynecol Obstet 1947;83:129-146.

17. Abecasis N, Cortez F, Bettencourt A, Costa CS, Orvalho F, Almedia JM. Surgical treatment of lung metastases: prognostic factors for long-term survival. J Surg Oncol. 1999;72:193-8.

18. Margaritora S, Porziella V, D’Andrilli A, Cesario A, Galetta D, Macis G, et al. Pulmonary metastases: can accurate radiological evaluation avoid thoracotomic approach? Eur J Cardiothorac Surg 2002;21:1111-4.

19. Younes RN, Gross JL, Taira AM, Martins AAC, Neves GS. Surgical resection of lung metastases: results from 529 patients. Clinics 2009;64:535-41.

20. Snyder BJ, Pugatch RD. Imaging characteristics of metastatic diseases to the chest. Chest Surg Clin N Am 1998;8:29-33.

21. Mery CM, Pappas AN, Bueno R, Mentzer SJ, Lukanich JM, Sugarbaker DJ et al. Relationship between a history of antecedent cancer and the probability of malignancy for a solitary pulmonary nodule. Chest 2004; 125:2175-81 